\title{
Hypoinsulinemic hypoglycemia and body hemihypertrophy
}

INSERM

\section{Source}

INSERM. (1999). Orphanet: an online rare disease and orphan drug data base.

Hypoinsulinemic hypoglycemia and body hemihypertrophy. ORPHA:293964

Hypoinsulinemic hypoglycemia and body hemihypertrophy is a rare, genetic, endocrine disease characterized by neonatal macrosomia, asymmetrical overg rowth (typically manifesting as left-sided hemihypertrophy) and recurrent, severe hypoinsulinemic (or hypoketotic hypo-fatty-acidemic) hypoglycemia in infancy, which results in episodes of reduced consciousness and seizures. 